\title{
Chromosome Preparation and Preliminary Observation of Two Amphioxus Species in Xiamen
}

\author{
ZHANG Qiu-jin ${ }^{1,2}$, LI Guang ${ }^{2}$, SUN Yi ${ }^{2}$, WANG Yi-quan ${ }^{2, *}$ \\ (1. College of Life Sciences, Fujian Normal University, Fuzhou 350108, China; \\ 2. School of Life Sciences, Xiamen University, Xiamen 361005, China)
}

\begin{abstract}
Amphioxus has an important evolutionary position as a result of their phylogenetic position relative to vertebrates. Understanding their chromosomes would provide key points in the study of evolutionary biology and comparative genomics. The difficulty in preparing amphioxus chromosomes currently provides a significant hurdle in this research. In the current study, we describe an improved method for metaphase preparation from amphioxus embryos and methodology for preparing metaphase spreads from regenerative somatic cells. Chromosomes of two amphioxus species from Xiamen waters in China are also observed. The diploid chromosome number was found to be 40 in Branchiostoma belcheri, while B. japonicum has 36, confirming the two are distinct species from cytotaxonomic viewpoint.
\end{abstract}

Key words: Amphioxus (lancelet); Branchiostoma belcheri; B. japonicum; Chromosome; Regenerative cell

\section{厦门两种文昌鱼染色体的制备与观察}

\author{
张秋金 ${ }^{1,2}$, 李 光 ${ }^{2}$, 孙 毅 2 , 王义权 ${ }^{2, *}$ \\ (1. 福建师范大学 生命科学学院, 福州 350108; 2. 厦门大学 生命科学学院, 厦门 361005)
}

摘要: 文昌鱼的进化地位十分重要, 对其染色体的研究在进化和比较基因组学方面有重要意义。然而文昌鱼 的染色体制备困难，使研究受到了限制。本文介绍了一种改良的文昌鱼胚胎细胞染色体标本制备方法，以及用文 昌鱼成体再生细胞制备染色体, 首次获得了文昌鱼体细胞中期染色体标本, 并观察了厦门 2 种文昌鱼的染色体, 其中白氏文昌鱼（Branchiostoma belcheri）二倍体 $2 n=40$, 日本文昌鱼（B. japonicum）二倍体 $2 n=36$ 。再次从细胞 分类学角度证实白氏文昌鱼和日本文昌鱼作为两个独立物种的分类地位。

关键词: 文昌鱼; 白氏文昌鱼; 日本文昌鱼；染色体；再生细胞

中图分类号: Q959.287; Q951.3; Q343.2 文章标识码：A 文章编号：0254-5853-(2009)02-0131-06

Lancelets, or amphioxus, belong to Subphylum Cephalochordata, which include about 30 species of small marine animals. They share key anatomical and developmental features with vertebrates, including a dorsal hollow nerve cord, a notochord, pharyngeal gill slits, segmental muscles and a post-anal tail. However, the amphioxus genome lacks the extensive gene duplications like that happened in vertebrates (Holland et al, 2004; Putnam et al, 2008) and its body plan is similar to that of a simplified vertebrate. As a result of its phylogenetic relationship to vertebrates, the lancelets play an important role in the study of evolutionary and developmental biology.

Investigation of amphioxus chromosomes will provide important information regarding chromosome evolution and comparative genomics. Although Stricht alluded to the chromosomes of Branchiostoma lanceolatum in the descriptions of amphioxus ovogenesis in 1895 (see Howell \& Boschung, 1971), the study of amphioxus chromosomes progressed slowly due to the difficulties in preparing metaphase spreads. No somatic tissue with high mitotic index was found for metaphase preparation. So far, the chromosome numbers of only three lancelets B. belcheri (actually B. japonicum), B.

Received date: 2008-11-25; Accepted date: 2009-03-11

Foundation items: Supported by grants from NSFC (No.30570208); SRFDP of Ministry of Education, China (20070384041); The Education Department of Fujian Province, China (JB07063)

*Corresponding author (通讯作者), E-mail: wangyq@xmu.edu.cn

收稿日期: 2008-11-25；接受日期：2009-03-11 
floridae and B. lanceolatum were reported, and all of those chromosomes were prepared from male gonad tissue (Nogusa, 1957; Howell \& Boschung, 1971; Colombera, 1974; Saotome \& Ojima, 2001). The amphioxus chromosomes are extremely small and gently grade in size and their shape is very similar to each other (Howell \& Boschung, 1971; Colombera, 1974; Saotome \& Ojima, 2001; Wang et al, 2003). All of these restrict the progress in the study of amphioxus chromosome and consequently, only the chromosome numbers of three lancelets were available for a long period. Until 2002, Castro \& Holland firstly used amphioxus embryos to prepare metaphase spreads, which led to the new achievements in the karyotype (Wang et al, 2003), banding pattern (Wang et al, 2004; Zhang et al, 2004) and gene mapping (Castro \& Holland, 2002, 2003; Castro et al, 2004; Luke et al, 2003; Minguillón et al, 2004).

The metaphase preparation from amphioxus gonads or embryos can only be conducted in the breeding season. In addition, some problems need to be overcome when the embryonic metaphases are prepared according to the previous protocols (see below). In this study, we report a modified method for preparing amphioxus metaphase spreads from embryos and describe a method for preparing metaphase spreads from regenerative somatic cells. We also observe the chromosome numbers of two amphioxus species from Xiamen, China, and provide new cytotaxonomic data to demonstrate that $B$. belcheri and B. japonicum are distinct species.

\section{Materials and Methods}

\subsection{Metaphase preparation from embryos}

All samples used in the present study were morphologically identified according to our previous reports (Xu et al, 2005; Zhang et al, 2006). Two lancelets $B$. belcheri and B. japonicum collected from Xiamen Rare Marine Creature Conservation Areas (Fujian, China) were cultured in the laboratory (Zhang et al, 2007). During spawning nights, the fertilized eggs were collected by filtering through 100 mesh nylon net. After rinsed in fresh seawater the embryos were cultured in Petri dish with filtered seawater at room temperature (about $25^{\circ} \mathrm{C}$ ). Embryos at blastula or early gastrula stages were used to prepare metaphase spreads. After pretreated in filtered seawater containing $20 \mu \mathrm{g} / \mathrm{mL}$ colchicine for $20 \mathrm{~min}$, the embryos were suctioned gently via a Pasteur pipette (with the tip 200-300 $\mu \mathrm{m}$ inside diameter) to destroy the fertilization envelopes and disperse embryonic cells. The embryonic cells were harvested by centrifuging at $700 \mathrm{r} / \mathrm{min}$ for $5 \mathrm{~min}$ and treated in the hypotonic $\mathrm{KCl}$ solution $(187.5 \mathrm{mmol} / \mathrm{L})$ with an appropriate volume for $40 \mathrm{~min}$. For pre-fixation treatment to the cells, about 0.1 volume of fresh methanol: glacial acetic acid $(3: 1)$ were added into the hypotonic solution and mixed gently, then the cells were harvested immediately via centrifugation (700 r/min for $5 \mathrm{~min}$ ). The harvested cells were fixed with fresh methanol:glacial acetic acid fixative $(3: 1)$. The fixative was changed 2 times over a period of $1 \mathrm{~h}$. The fixed embryonic cells were suspended with a little fresh fixative, and the preparations were produced by dropping the suspension onto slides (50 to $100 \mu \mathrm{L}$ per slide).

\subsection{Metaphase preparation from regenerative cells}

The somatic metaphase spreads were prepared from regenerative cells. The animals were cut on the tailend and then cultured normally feeding with unicellular algae for 2 or 3 days. When new tail calluses started growing, the animals were treated in seawater containing 20-30 $\mu \mathrm{g} / \mathrm{mL}$ colchicine for $40 \mathrm{~min}$ to $2 \mathrm{~h}$ at about $25^{\circ} \mathrm{C}$. Subsequently, the tail calluses containing lots regenerative cells were cut off about $1 \mathrm{~mm}$ along the wound and dissociated into extremely tiny pieces (most of them were single cells) in $10 \mu \mathrm{L}$ seawater with knives under stereoscope. The cells were directly suspended with 1 to $2 \mathrm{~mL}$ hypotonic $\mathrm{KCl}$ solution $(187.5 \mathrm{mmol} / \mathrm{L})$ and the suspension was dropped onto a glass slide which was placed over two glass bars in Petri dish $10 \mathrm{~cm}$ in diameter (following $\mathrm{Wu}$, 1982). After hypotonic treatment for $40 \mathrm{~min}$, about $15 \mathrm{~mL}$ fresh fixative solution of ethanol: glacial acetic acid: distilled water $(1: 2: 3 \mathrm{~V} / \mathrm{V})$ were added into Petri dish and the cells were fixed for 1 to $2 \mathrm{~h}$ with vapor. Then the fixative was replaced with ethanol and the cells were fixed again for $20 \mathrm{~min}$. During the hypotonic treatment and fixation, extreme caution is necessary to prevent the suspension overflowing the slide. Finally, the slide was tilted to drain hypotonic solution and washed with fresh solution of ethanol: glacial acetic acid $(1: 2 \mathrm{v} / \mathrm{v})$.

The preparations were air-dried and then stained with $10 \%$ Giemsa for $10 \mathrm{~min}$. The metaphase chromosomes were observed and photographed under a BX41 Olympus microscope.

\section{Results}

Using the improved method, we produced large numbers of metaphase spreads from embryonic cells of $B$. belcheri and B. japonicum. The chromosomes were 
almost homogeneously stained with Giemsa, and showed a gentle gradation in size. The chromosome shape was not obviously different in the spreads (Fig. 1). It was difficult to distinguish individual chromosome and to define the chromatids and centromeres in most spreads (Fig. 1A, C). Only in a few cases could the chromatids be defined (Fig. 1B, D).

In the present study, we also prepared metaphase spreads from regenerative cells of the two lancelets (Fig. 2). Metaphase spreads, mounted in slides, were observed from each animal with the exception of old individuals.
The chromosomes are extremely small and present both rod and dot shape. As mentioned above, the chromatids and centromeres were also difficult to define in somatic metaphase spreads.

Two hundred embryonic metaphase spreads of each species were observed randomly and their chromosome numbers counted. The chromosome numbers ranged from 32 to 50 for $B$. belcheri, and from 27 to 38 for $B$. japonicum, with modal diploid numbers (2n) of 40 $(80.5 \%)$ and $36(81.5 \%)$ respectively (Fig. 3$)$.

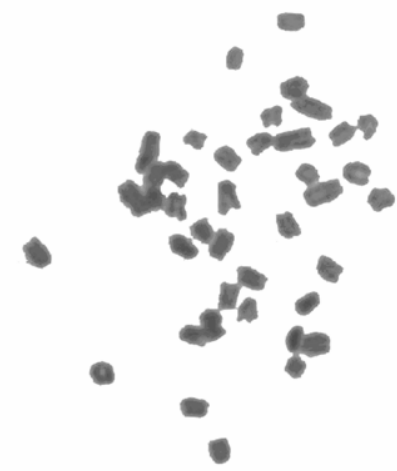

$$
\text { A }
$$
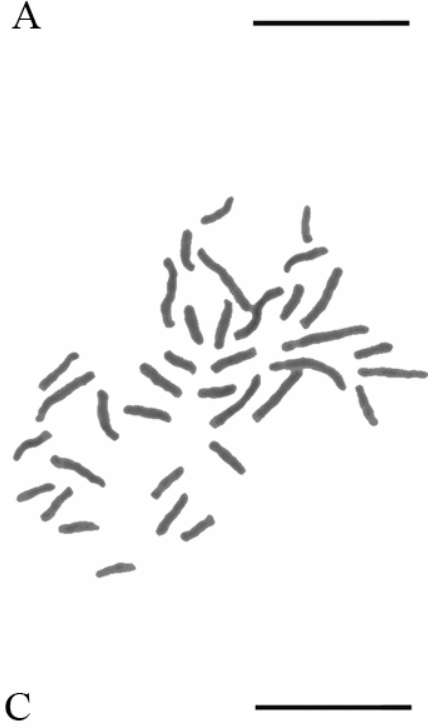

B

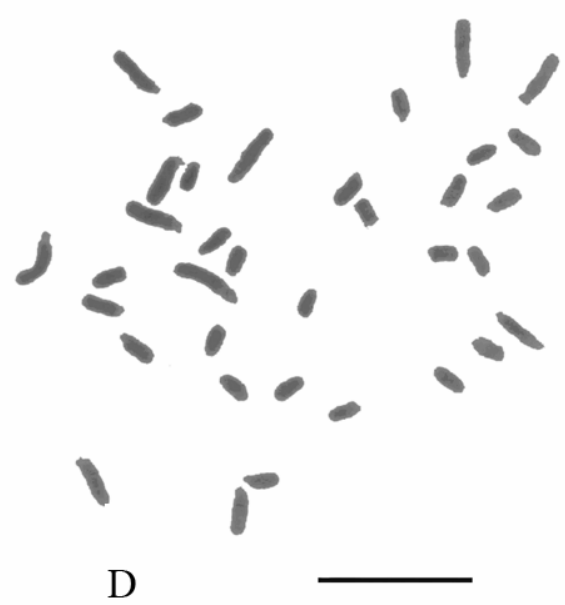

Fig. 1 The metaphase spreads from embryos of Branchiostoma belcheri (A, B) and B. japonicum (C, D). Bars: $10 \mu \mathrm{m}$

\section{Discussion}

Castro \& Holland (2002) firstly prepared metaphase chromosomes from amphioxus embryos using a more complex protocol. Wang et al $(2003,2004)$ and Zhang et al (2004) also prepared metaphase spreads from embryos and observed the karyotype and banding patterns of $B$. belcheri tsingtauense (actually B. japonicum). However, some problems arose during metaphase preparation according to the methods described by Wang et al (2003). It was difficult to settle the embryos due to the buoyant force on the fertilization envelopes. Moreover, the envelopes were not destroyed and the embryonic cells were not dissociated well before slide preparation, which resulted in overlapping of the metaphase spreads. Mu et al (2005) used the same protocol described by Wang et al (2003) and also implied that it was difficult to get better spreads. In order to solve these problems, we destroyed 


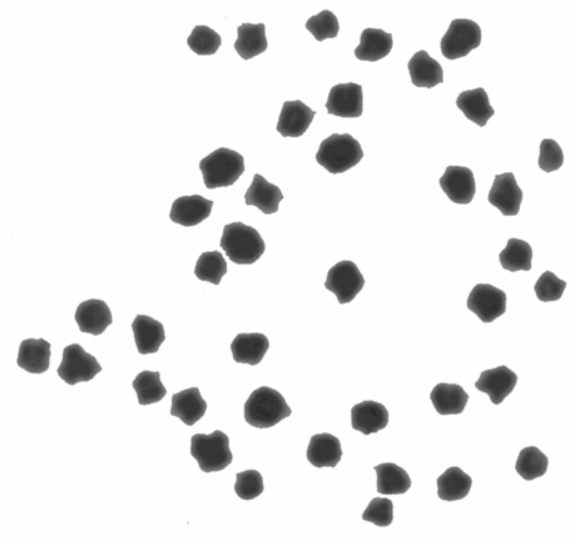

A
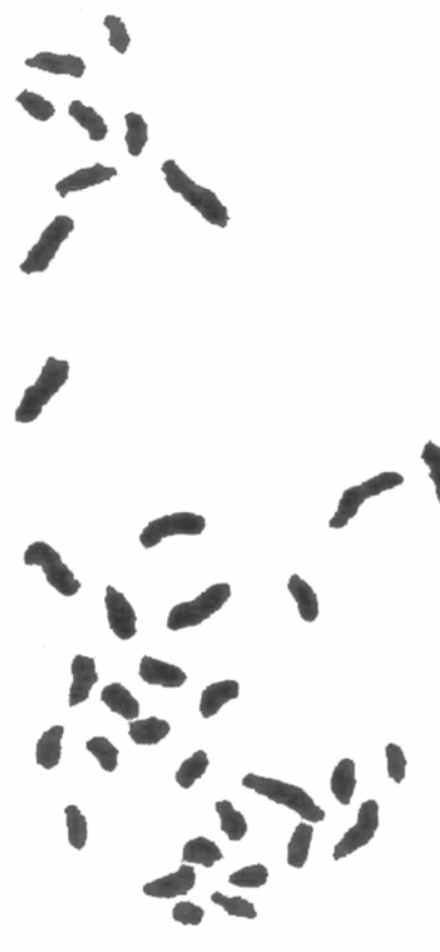

C

Fig. 2 The metaphase spreads from regenerative somatic cells of Branchiostoma belcheri (A: female, B: male) and B. japonicum (C: female, D: male). Bars: $10 \mu \mathrm{m}$

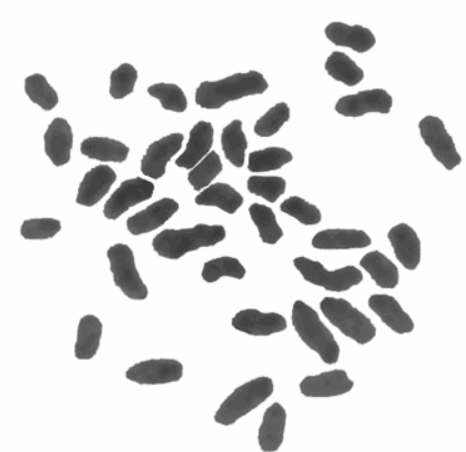

B

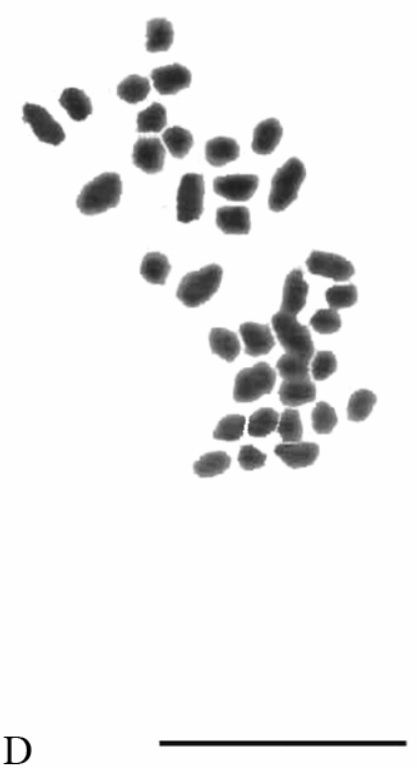

the envelopes prior to hypotonic treatment. However, the dissociated cells almost burst in the common hypotonic solution $(75 \mathrm{mmol} / \mathrm{L} \mathrm{KCl})$. This highlighted the need for a hypotonic solution concentration suitable for lancelet cells. We found that the $\mathrm{KCl}$ solution of $187.5 \mathrm{mmol} / \mathrm{L}$ concentration was suitable for lancelet cells.

The length of chromosome was significantly related to the concentration of colchicine and the duration of treatment. When Castro \& Holland (2002) pretreated the embryos with $250 \mu \mathrm{g} / \mathrm{mL}$ colchicine for $30 \mathrm{~min}$ and Wang et al $(2003,2004)$ pretreated them with $50 \mu \mathrm{g} / \mathrm{L}$ or 40 $\mu \mathrm{g} / \mathrm{mL}$ for $30 \mathrm{~min}$, they obtained most metaphase spreads with short chromosomes. We found that most spreads had stretched chromosomes when embryos were pretreated with $20 \mu \mathrm{g} / \mathrm{mL}$ colchicine for 15 to $20 \mathrm{~min}$ at room temperature.

So far, no amphioxus chromosomes have been prepared from somatic tissue in previous reports. Howell \& Boschung (1971) failed in preparing spreads from gill and fin epithelia. Moreover, the testes and embryos 


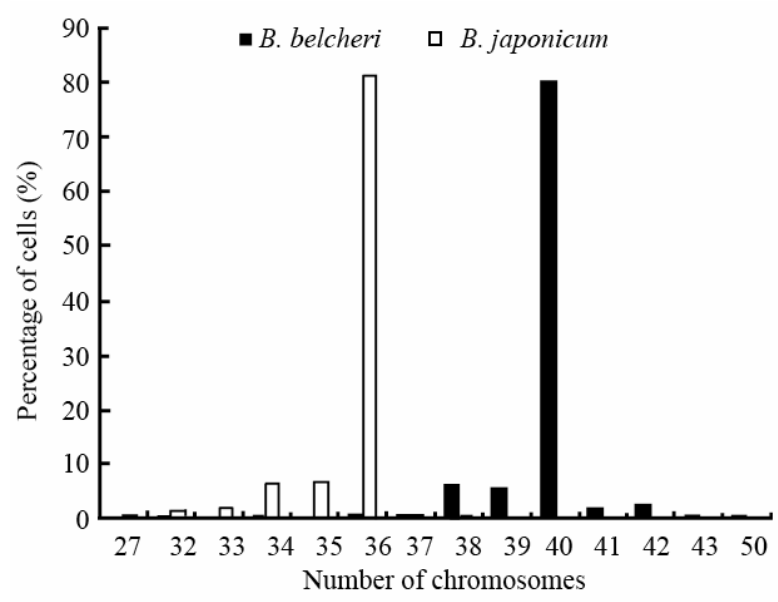

Fig. 3 Observed frequency distribution of chromosome numbers in two lancelets Branchiostoma belcheri and B. japonicum

of lancelet could only be obtained in a given season. Thus, the successful preparation from regenerative cells will be helpful in studying amphioxus chromosomes. To prepare metaphase from regenerative cells, it was necessary to pretreat the animals with colchicine. When the animals were pretreated in $20 \mu \mathrm{g} / \mathrm{mL}$ colchicine for $40 \mathrm{~min}$ and $1 \mathrm{~h}$, the chromosomes presented rod (Fig. $2 \mathrm{~B}$, C) and short-rod shape (Fig. 2 D) respectively. The chromosomes became shorter with the increase of colchicine concentration or treatment duration. When the animals were pretreated in $30 \mu \mathrm{g} / \mathrm{mL}$ for $2 \mathrm{~h}$, the chromosomes were dot-shaped (Fig. 2 A).

Furthermore, Nogusa (1957) claimed the presence of pair of XY sex-chromosome in B. belcheri (actually $B$. japonicum), and Wang et al $(2003,2004)$ also suggested that the second pair of chromosomes in $B$. belcheri tsingtauense might be sex-chromosomes but the chromosome type (XY or ZW) remain to be clarified. This issue could be resolved by increasing the number of metaphases, and the corresponding G-banded chromosomes, observed from two sex distinguishable

\section{References:}

Castro LFC, Furlong RF, Holland PWH. 2004. An antecedent of the $M H C$-linked genomic region in amphioxus[J]. Immunogenetics, 55: $782-784$.

Castro LFC, Holland PWH. 2002. Fluorescent in situ hybridisation to amphioxus chromosomes[J]. Zool Sci, 19: 1349-1353.

Castro LFC, Holland PWH. 2003. Chromosomal mapping of ANTP class homeobox genes in amphioxus: Piecing together ancestral genomes[J]. Evol Dev, 5: 459-465.

Colombera D. 1974. Male chromosomes in two populations of Branchiostoma lanceolatum[J]. Experientia, 30: 353-355.

Holland LZ, Laudet V, Schubert M. 2004. The chordate amphioxus: an individuals. Unfortunately, we failed to find the chromosome difference between female and male due to their small and similar chromosomes.

Although Nogusa (1957) reported the diploid number of $B$. belcheri collected from Japan was $2 n=32$, Saotome \& Ojima (2001) found that the diploid number of the same species in Japanese waters was $2 n=36$. Taxonomically, the amphioxus distributed in Japan was identified as the same subspecies as those in Qingdao, China, i.e. B. belcheri tsingtauense (Nishikawa, 1981). Indeed, Wang et al (2003) also found that the chromosome number of amphioxus from Qingdao is $2 n=36$. Recent taxonomic studies demonstrated that there are two distinct amphioxus species in Xiamen waters (Wang et al, 2004; Xu et al, 2005), and the further morphologic observation and molecular data comparison revealed one of the species is $B$. belcheri and the other is the same species as Qingdao amphioxus (Zhang et al, 2006; Zhong et al, 2009). The philological study showed the name of the latter should be revised to B. japonicum according to the rule of priority (Wang \& Fang, 2005; Zhang et al, 2006). In the present study, our chromosome counting results indicate that $B$. belcheri $(2 \mathrm{n}=40)$ and $B$. japonicum $(2 n=36)$ from Xiamen have different diploid numbers. This observation provides cytogenetic evidence to further confirm the two distinct species. The diploid number $2 n=36$ of $B$. japonicum sampled from Xiamen is the same as that of Qingdao and Japanese amphioxus, indicating lancelets distributed in those area belong to the same species. This result is consistent with the previous studies based on the DNA sequences and morphological observation. Thus, we conclude that the amphioxus with $2 \mathrm{n}=36$ in previous reports is $B$. japonicum, not $B$. belcheri tsingtauense or $B$. belcheri. Instead, this study is the first to report a diploid number of $2 n=40$ for $B$. belcheri.

emerging model organism for developmental biology[J]. Cell Mol Life Sci, 61: 2290-2308.

Howell WM, Boschung Jr HT. 1971. Chromosomes of the lancelet, Branchiostoma floridae (Order Amphioxi)[J]. Experientia, 27: 1495-1496.

Luke GN, Castro LFC, McLay K, Bird C, Coulson A. Holland PWH. 2003. Dispersal of NK homeobox gene clusters in amphioxus and humans[J]. Proc Natl Acad Sci USA, 100: 5292-5295.

Minguillón C, Gardenyes J, Serra E, Castro LFC, Hill-Force A, Holland PWH, Amemiya CT, Garcia-Fernàndez J. 2004. No more than 14: the end of the amphioxus Hox cluster[J]. Int J Biol Sci, 1: 
19-23.

Mu H, Wang C, Li J. 2005. The study of the separate amphioxus chromosome pattern[J]. Life Sci Instruments, 3: 27-28. (in Chinese)

Nishikawa T. 1981. Consideration on the taxonomic status of the lancelets of the genus Branchiostoma from the Japanese waters[J]. Publ Seto Mar Biol Lab, 26: 135-156.

Nogusa S. 1957. The chromosomes of the Japanese lancelets Branchiostoma belcheri (Gray), with special reference to the sex-chromosome[J]. Annot Zool Jap, 30: 42-46.

Putnam NH, Butts T, Ferrier DEK, Furlong RF, Hellsten U, Kawashima T, Robinson-Rechavi M, Shoguchi E, Terry A, Yu JK, Benito-Guti é rrez È, Dubchak I, Garcia-Fernàndez J, Gibson-Brown JJ, Grigoriev IV, Horton AC, Jong PJd, Jurka J, Kapitonov VV, Kohara Y, Kuroki Y, Lindquist E, Lucas S, Osoegawa K, Pennacchio LA, Salamov AA, Satou Y, Sauka-Spengler T, Schmutz J, Shin-I T, Toyoda A, Bronner-Fraser M, Fujiyama A, Holland LZ, Holland PWH, Satoh N, Rokhsar DS. 2008. The amphioxus genome and the evolution of the chordate karyotype[J]. Nature, 453: 1064-1072.

Saotome K, Ojima Y. 2001. Chromosomes of the lancelet Branchiostoma belcheri Gray[J]. Zool Sci, 18: 683-686.

Wang C, Zhang S, Chu J. 2004. G-banding patterns of the chromosomes of amphioxus Branchiostoma belcheri tsingtauense $[\mathrm{J}]$. Hereditas, 141: 2-7.

Wang C, Zhang S, Zhang Y. 2003. The karyotype of amphioxus Branchiostoma belcheri tsingtauense (Cephalochordata)[J]. Mar
Biol Ass UK, 83: 189-191.

Wang YQ, Fang SH. 2005. Taxonomic and molecular phylogenetic studies of amphioxus: A review and prospective evaluation[J]. Zool Res, 26(6): 666-672. (in Chinese)

Wang YQ, Xu QS, Peng XX, Zhou HT. 2004. Taxonomic status of amphioxus Branchiostoma belcheri in Xiamen Beach estimated by homologous sequence of Cyt $b$ gene[J]. Acta Zool Sin, 50(2): 185-190. (in Chinese)

Wu Z. 1982. A simple method for chromosome preparation from amphibian bone marrow cells[J]. Hereditas (Beijing), 4(1): 38-39. (in Chinese)

Xu QS, Ma F, Wang YQ. 2005. Morphological and 12S rRNA gene comparison of two Branchiostoma species in Xiamen waters[J]. $J$ Exp Zool (Mol Dev Evol), 304B: 259-267.

Zhang QJ, Zhong J, Fang SH, Wang YQ. 2006. Branchiostoma japonicum and B. belcheri are distinct lancelets (Cephalochordata) in Xiamen waters in China[J]. Zool Sci, 23: 573-579.

Zhang QJ, Sun Y, Zhong J, Li G, Lü XM, Wang YQ. 2007. Continuous culture of two lancelets and production of the second filial generations in the laboratory[J]. J Exp Zool (Mol Dev Evol), 308B: 464-472.

Zhang S, Wang C, Chu J. 2004. C-banding pattern and nucleolar organizer regions of amphioxus Branchiostoma belcheri tsingtauense[J]. Genetica, 121: 101-105.

Zhong J, Zhang QJ, Xu QS, Schubert M, Laudet V, Wang YQ. 2009. Complete mitochondrial genomes defining two distinct lancelet species in the West Pacific Ocean[J]. Mar Biol Res, (in Press). 